\title{
Feeding our autonomy: resilience in the face of the CoVid-19 and future pandemics
}

\author{
Fatuma Emmad ${ }^{1}$. Devon G. Peña ${ }^{2}$
}

Accepted: 25 April 2020 / Published online: 20 May 2020

C) Springer Nature B.V. 2020

Food sovereignty activists have long talked about those who the food system has oppressed. Magazine articles and raised eyebrows may lead you to believe this is a dirty hidden secret. It was always visible to us. Suffering is now affecting everyone from the farmers, ranchers, and landowners to the farm workers, processing plant, and packaging workers. All those people squeezed into a category of consumer are dependent on those whose lives and work are under direct siege. The lament that our food system is broken obfuscates its success: the U.S. food system operates as a capitalist dream built on endless exploitation of the land and workers.

As food is plowed into fields and milk is dumped we see surging outrage that echoes the calls of our communities for so long. Food is being wasted while people need it but this has long been the case in a nation in which the norm means more than $40 \%$ of our food is wasted. We have lived in a reality where Earth guardians, Indigenous peoples, Black and Latinx farmers, and all the non-binaries who could not be placed into data points are no longer equated with being radicals and are finally seen as people speaking truth to power.

We are more than simply qualitative data and informants for ethnographers. We are still here and we have been here despite the labels of "illegal aliens" or essential workers. Despite the manic fluctuations of American morality our value as those who feed a nation has not escaped notice. We carried the ways and knowledge of cultivating land and communities from our homes under attack for water, soy, and avocado dreams. We wove seeds into our hair as we were

This article is part of the Topical Collection: Agriculture, Food \& Covid-19.

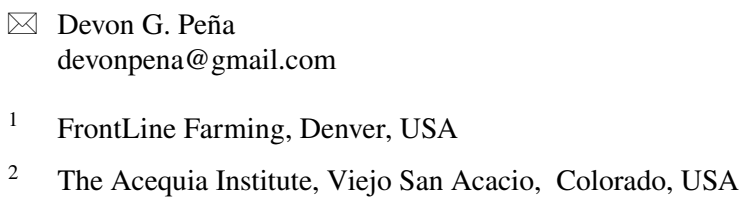

\begin{tabular}{ll}
\hline$\square$ & $\begin{array}{l}\text { Devon G. Peña } \\
\text { devonpena@gmail.com }\end{array}$ \\
1 & FrontLine Farming, Denver, USA \\
2 & The Acequia Institute, Viejo San Acacio, Colorado, USA
\end{tabular}

Publisher's Note Springer Nature remains neutral with regard to jurisdictional claims in published maps and institutional affiliations. banks as initial attacks.

This crisis has lifted a veil which makes us begin to understand isolation and division are not natural and pain or suffering are more than a matter of theoretical debates. The struggles we have faced are collective whether we could see it or not. Our nation was ill-prepared for this crisis but we see people standing up in every profession filled with rage at the ignorance and inhumanity breaking through to the surface. Speaking about immigration to food systems specialists is no longer seen as a radical concept. We are no longer looking at poverty as something to punish. We are the answers we seek.

Both of us are members of a task force developing proposals for Governor Jared Polis (D-Colorado) to ensure that farm workers, undocumented and those with legal status, are extended relief assistance for food, shelter, health care, and lost income. Any failure to include all farm workers with emergency relief will undermine the nation's ability to feed itself. One of our members, a woman who is a farm worker and organizer, explained how farm workers are not in panic mode. They are surviving by turning to one other in the tradition of mutual aid and informal networking that have always been our self-reliance safety net. She explained how farm workers are always saving up for that rainy day and neighbors always care for each other. We have managed to stay connected to each other and our foodways through mutual reliance even as food has changed under colonialism, slavery, and the modern exploitation of farm workers. Food is a last line of dignity for humans. It is what leads to revolutions.

\footnotetext{
jurisdictional claims in published maps and institutional affiliations.
}

forced from our homes and we watched wars bomb our seed

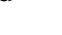


Fatuma Emmad is the co-founder of Front Line Farms, and the owner and operator of Bountiful By Design, a sustainable high-end landscape company. She is also an affiliate Professor at Regis University in the Community Food Systems minor. Fatuma was born in Denver and raised in Denver and Ethiopia.

Devon G. Peña is Professor of American Ethnic Studies and Anthropology at the University of Washington. He is also the Founder and President of The Acequia Institute, a foundation supporting the environmental and food justice movements. His most recent book, Mexican-Origin Foods, Foodways, and Social Movements: Decolonial Perspectives (2017, U. of Arkansas Press) has received several awards including Best Edited Volume (2018) from the Association for the Study of Food and Society. 